\title{
The Evaluation of Land Use Status in Mountainous Counties of Southwest China Based on Comprehensive Evaluation Models: A Case Study of Baoxing County, Sichuan Province
}

\author{
Mengtian Cao ${ }^{1, *}$, Jundi Shen ${ }^{1}$, Zhehua Chen $^{2}$ \\ ${ }^{1}$ School of Tourism management, South China Normal University, Panyu district, No.378 Waihuan West Road, Guangzhou, 510006, \\ Guangdong, P.R.China. \\ ${ }^{2}$ Guangdong Forestry Survey and Planning Institute, Tianhe district, No.338 Guangshan 1st Road, Guangzhou, 510520, Guangdong, \\ P.R.China.
}

\begin{abstract}
In mountainous areas of Southwest China, the land resources are scarce, and the ecological environment is fragile, so it is particularly important to carry out the evaluation of land use status for the sustainability of land development. Taking Baoxing County in Sichuan Province, the typical mountainous county in Southwest China, as an instance, this study refers to the existing research frameworks to establish the evaluation system of land use status. Meanwhile, the comprehensive evaluation models are used to evaluate land use status. As indicated from the results, in Baoxing County, the comprehensive evaluation score of the overall status of land use, the evaluation score of the development degree of land, the evaluation score of the intensive management degree of land and the evaluation score of the comprehensive benefits of land were $83.5,108.24,72.25$ and 80.77 , respectively. Land use status is generally at the relatively rational use stage, and the main problems are the lack of land investment and the low mechanization level of agricultural production. It is suggested to increase the financial investment in land and enhance the intensive degree and comprehensive benefits of land in the future.
\end{abstract}

\section{Introduction}

With an area of about $2 / 3$ of China's territory area, China's mountainous areas are characterized by the complex geological environment, the scattered land resources and the outstanding contradictions between limited land resources and rapid urbanization. With the increase of population and the rapid improvement of urbanization rate, the industrialization degree is also being enhanced constantly. Under the pressure of these leading factors, the scales of industrial land and urban and rural construction land have been expanded gradually, which not only poses great challenges to the maintenance of limited land resources in mountainous areas but also can lead to the destruction of ecological environment in mountainous areas. Therefore, the reasonable development and use of the existing land resources in mountainous areas and the environmental management are crucial to ensuring the sustainable development of mountainous areas. However, the development and use of land in mountainous areas should be based on the evaluation of land use status, so as to carry out the overall planning and layout.

As a multi-level and multi-factor complex study, the evaluation of land use status is an analytical evaluation of characteristics, utilization structure and layout, use degree, utilization effect and existing problems of land resources in the research area, and the evaluation results are influenced by natural, human and other factors. The land evaluation frameworks are divided into three categories, namely the Goal-EstimateConsequence(G-E-C) evaluation framework from "The Outline of Land Evaluation" and "The Outline of Sustainable Land Management Evaluation" (which analyzes the evaluation based on identifying the objectives, types and methods of land use), the Pressure-Status-Response (P-S-R) framework put forward by Organization for Economic Cooperation and Development (which emphasizes the evaluation of land based on the analysis on the correlations among human activities, social development and ecological environment) and the Nature -Economy-Society (N-E-S) framework (which analyzes the land use system as the natural, economic and social subsystems to measure the integrity of the land system and realize the dimensionality reduction of the complex system). The above frameworks play an important role in the overall evaluation of land, the quantification of relevant indicators and the environmental management.

At present, the statistical and econometric model analysis methods are mainly adopted for the land evaluation methods, and the relevant technical support is used. For example, overlap analysis method,

\footnotetext{
* Corresponding author: caomt@m.scnu.edu.cn (M. Cao) ;
} 
multi-indicator decision model, vector-raster mixed data model, Markov model, neighborhood algorithm and GRNN model are used for land evaluation. The land is technically evaluated by GIS, RS, GPS and other means. Currently, there is the lack of the research on the evaluation of land use status in mountainous counties of Southwest China. As the giant panda habitat, Baoxing County belongs to the restricted development zone in the main functional areas, and the ecological environment is fragile, so the case selection is representative. Thus, drawing lessons from the previous research frameworks, this study uses the comprehensive evaluation models to evaluate the current status of land and analyzes the current status and future development direction of land use in Baoxing County.

\section{Research region and data sources}

\subsection{General situations of research region}

Baoxing County $\left(102^{\circ} 28-103^{\circ} 02^{\prime} \mathrm{E}, 30^{\circ} 09^{\prime}-30^{\circ} 56^{\prime} \mathrm{N}\right)$ is located in the western edge of the Sichuan Basin and in the north of Ya'an City. Bordering Wenchuan County and Xiaojin County on the north and facing Tianquan County on the south, it is contiguous to Kangding County on the west and adjoins Lushan County on the east. The transportation is mainly based on highways, and provincial highway No. 210 runs through the whole territory. The county is $61 \mathrm{~km}$ wide from east to west and $81 \mathrm{~km}$ long from south to north, and the jurisdiction area is about $3114 \mathrm{~km} 2$.According to the second national land survey data, the total land area of Baoxing County is $311398.68 \mathrm{hm} 2$, and the agricultural land, construction land and unused land in the county respectively account for $95 \%, 1 \%$ and $4 \%$ of the county's total land area.

\subsection{Data sources}

The latest DEM (1:50000 data), administrative division map, present land use map, river system map, fracture structure map, traffic road map, population and related socio-economic data were obtained in accordance with the $\mathrm{MH}$ tracking survey and CL development in Baoxing County from research groups between 2014 and 2016. The data originated from the Statistical Bureau, Meteorological Bureau, Land Bureau, archives, geological environment monitoring stations and other relevant government departments of Baoxing County.

\section{Evaluation model calculation and design of evaluation indicator}

(1) Single indicator score calculation

In this study, the comprehensive evaluation models are used to preprocess the selected indicator magnitude uniformly. Formula (a) is used for the calculation of the scores of positive indicators, while Formula (b) is adopted to calculate the scores of negative indicators. The specific formulas are as follows:

$$
\begin{gathered}
F_{1}=C V / S V \times W_{i} \\
F_{2}=S V / C V \times W_{i}
\end{gathered}
$$

F1 and F2 refer to the score of the indicator; $\mathrm{CV}$ indicates the present value of the indicator (the current survey statistics); SV represents the standard value of the indicator (the target planning value in 2020); Wi denotes the weight.

(2) Evaluate the total score calculation

The calculation of the total score value of the evaluation is the linear weighting of the score of the individual evaluation indicator, and the formula can be expressed by:

$$
L S=\sum W_{i} F_{i}(i=1,2, \ldots, n)
$$

LS stands for the comprehensive level of land use; Wi refers to the weight of the indicator $\mathrm{i}$; Fi represents the evaluation score of the indicator $i$; $n$ denotes the number of indicators.

(3) Evaluation standard division

In order to deal with the data better and more intuitively, in this study, the total evaluation score is multiplied by 100 , and land use status is divided into four stages, which are irrational use stage, general rational use stage, relatively rational use stage and sustainable use stage. The details are shown in Table1.

\subsection{Design of evaluation indicators}

Based on the actual characteristics of Baoxing County and the availability of data, the evaluation indicator system of land use status is established. Meanwhile, this study collects the data from the economic, environmental, transportation, agricultural and other departments in the county, the target planning value of the current overall land use planning and other relevant data, delimiting the standard value of each individual indicator. The details are presented in Table 2 .

Table 1. Land use status evaluation score standard

\begin{tabular}{|c|c|c|c|c|}
\hline $\begin{array}{c}\text { Evaluation } \\
\text { total score }\end{array}$ & $<50$ & $50-70$ & $70-90$ & $>90$ \\
\hline Standard & $\begin{array}{c}\text { Iirrational } \\
\text { use stage }\end{array}$ & $\begin{array}{c}\text { General } \\
\text { rational } \\
\text { use } \\
\text { stage }\end{array}$ & $\begin{array}{c}\text { Relatively } \\
\text { rational } \\
\text { use stage }\end{array}$ & $\begin{array}{c}\text { Sustaina } \\
\text { ble use } \\
\text { stage }\end{array}$ \\
\hline
\end{tabular}

\subsection{Evaluation model calculation}

Table 2. The Evaluation System and Standard Value of Land Use in Baoxing County

\begin{tabular}{c|c|ccc}
\hline $\begin{array}{c}\text { Target } \\
\text { level }\end{array}$ & $\begin{array}{c}\text { Criterion level } \\
(\mathrm{B})\end{array}$ & $\begin{array}{c}\text { Indicator } \\
\text { level }(\mathrm{C})\end{array}$ & Calculation formula explanation & $\begin{array}{c}\text { Stand } \\
\text { ard }\end{array}$ \\
\hline & Land & Land reclamation rate $(\%)\left(\mathrm{C}_{1}\right)$ & $\begin{array}{c}\text { Cultivated land area / Total land } \\
\text { area } 100\end{array}$ & 1.28 \\
\hline
\end{tabular}




\begin{tabular}{|c|c|c|c|c|}
\hline \multirow{16}{*}{$\begin{array}{l}\text { Status of } \\
\text { land } \\
\text { utilization } \\
\text { (A) }\end{array}$} & \multirow{7}{*}{$\begin{array}{l}\text { development } \\
\left(\mathrm{B}_{1}\right)\end{array}$} & Land use rate $(\%)\left(\mathrm{C}_{2}\right)$ & Used land area / Total land area $\cdot 100$ & 99.19 \\
\hline & & Agricultural use rate of land $(\%)\left(\mathrm{C}_{3}\right)$ & $\begin{array}{l}\text { Agricultural land area / Total land } \\
\text { area } 100\end{array}$ & 98.65 \\
\hline & & Land construction use rate $(\%)\left(\mathrm{C}_{4}\right)$ & $\begin{array}{l}\text { Construction land area / Total land } \\
\text { area } 100\end{array}$ & 0.55 \\
\hline & & $\begin{array}{c}\text { Multiple-crop indicator of cultivated } \\
\text { land }(\%)\left(\mathrm{C}_{5}\right)\end{array}$ & $\begin{array}{c}\text { Annual crop sown area / Total area of } \\
\text { cultivated land } 100\end{array}$ & $\begin{array}{c}302.9 \\
7\end{array}$ \\
\hline & & Population density (\%) $\left(\mathrm{C}_{6}\right)$ & Total population / Total land area $\cdot 100$ & 21.74 \\
\hline & & Forest coverage rate $(\%)\left(\mathrm{C}_{7}\right)$ & Woodland area / Total land area $\cdot 100$ & 73.67 \\
\hline & & $\begin{array}{l}\text { Per capita area of construction land } \\
\qquad\left(\mathrm{hm}^{2}\right)\left(\mathrm{C}_{8}\right)\end{array}$ & $\begin{array}{c}\text { Total area of construction land / Total } \\
\text { population } 100\end{array}$ & 2.51 \\
\hline & \multirow{4}{*}{$\begin{array}{c}\text { Intensive } \\
\text { degree of land } \\
\left(\mathrm{B}_{2}\right)\end{array}$} & $\begin{array}{c}\text { Fertilizer application rate of per-unit } \\
\text { cultivated land }(\%)\left(\mathrm{C}_{9}\right)\end{array}$ & $\begin{array}{l}\text { Fertilizer application amount / } \\
\text { cultivated area } \cdot 100\end{array}$ & $\begin{array}{c}100.6 \\
9\end{array}$ \\
\hline & & Urbanization level $(\%)\left(\mathrm{C}_{10}\right)$ & $\begin{array}{l}\text { Urban population / Total } \\
\text { population } 100\end{array}$ & 43.00 \\
\hline & & $\begin{array}{l}\text { Investment intensity of fixed assets } \\
\text { in per-unit construction land }\left(\mathrm{C}_{11}\right)\end{array}$ & $\begin{array}{l}\text { Fixed assets investment / } \\
\text { Construction land }\end{array}$ & $\begin{array}{c}244.6 \\
9\end{array}$ \\
\hline & & Road network density $(\%)\left(\mathrm{C}_{12}\right)$ & Traffic land / Total land area 100 & 0.13 \\
\hline & \multirow{5}{*}{$\begin{array}{l}\text { Comprehensive } \\
\text { benefit of land } \\
\left(\mathrm{B}_{3}\right)\end{array}$} & $\begin{array}{l}\text { Output value of unit sown area (Ten } \\
\text { thousand yuan) }\left(\mathrm{C}_{13}\right)\end{array}$ & $\begin{array}{c}\text { Total agricultural output value / Crop } \\
\text { sown area }\end{array}$ & 1.86 \\
\hline & & $\begin{array}{l}\text { Output value of unit land area (Ten } \\
\text { thousand yuan) }\left(\mathrm{C}_{14}\right)\end{array}$ & $\begin{array}{c}\text { Total agricultural output value / } \\
\text { Cultivated land area }\end{array}$ & 9.85 \\
\hline & & $\begin{array}{l}\text { Total output value of per-unit } \\
\text { agricultural land (Ten thousand } \\
\text { yuan) }\left(\mathrm{C}_{15}\right)\end{array}$ & $\begin{array}{c}\text { Total agricultural output value / } \\
\text { Agricultural land area }\end{array}$ & 0.13 \\
\hline & & Land output rate $(\%)\left(\mathrm{C}_{16}\right)$ & $\mathrm{GDP} /$ Land area $\cdot 100$ & 84.39 \\
\hline & & $\begin{array}{l}\text { Per capita area of cultivated land } \\
\qquad\left(\mathrm{hm}^{2}\right)\left(\mathrm{C}_{17}\right)\end{array}$ & $\begin{array}{c}\text { Total area of cultivated land / total } \\
\text { population }\end{array}$ & 0.06 \\
\hline
\end{tabular}

\section{Evaluation result and analysis of land use status quo}

\subsection{Land use status evaluation weight calculation}

The weights of the evaluation indicators of land use status are mainly determined by analytic hierarchy process (AHP), and the specific steps are as follows:(1)The establishment of the hierarchy judgment matrix;(2)The establishment of the related hierarchy sorting;(3)The consistency test of the judgment matrix;(4)The establishment of the related hierarchical level weight; In accordance with the above steps, the weights of various indicators are eventually calculated ( Fig.1.).

\subsection{Land use status evaluation score}

The calculation results of the above weight values are substituted into Formula (c), and through calculation, it is concluded that the evaluation score of land use status in Baoxing County was 83.50. The scores and comprehensive scores of the main individual indicators are detailed in Table 3. From the overall evaluation standard delineated in Table 1, it is seen that land use status in Baoxing County was generally at the sustainable use stage.

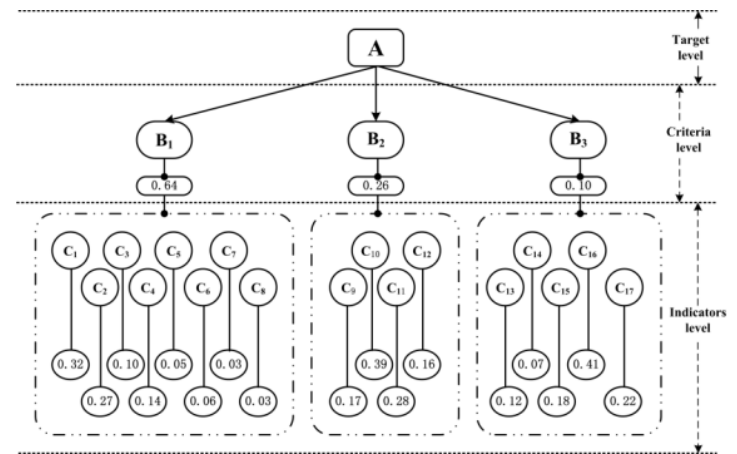

Figure 1. Evaluation indicators weight of land use status in Baoxing county

Table 3. Land use status evaluation score standard

\begin{tabular}{c|c|cccc}
\hline $\begin{array}{c}\text { Target level } \\
\text { (A) }\end{array}$ & $\begin{array}{c}\text { Criteria level } \\
\text { (B) }\end{array}$ & $\begin{array}{c}\text { indicator level } \\
\text { (C) }\end{array}$ & Statistic & $\begin{array}{c}\text { Single } \\
\text { indicator score }\end{array}$ & $\begin{array}{c}\text { Composite } \\
\text { Score }\end{array}$ \\
\hline $\mathrm{A}$ & & $\mathrm{C}_{1}$ & 1.38 & 107.31 & 108.24 \\
$(83.50)$ & & $\mathrm{C}_{2}$ & 95.88 & 96.66 & \\
\hline
\end{tabular}




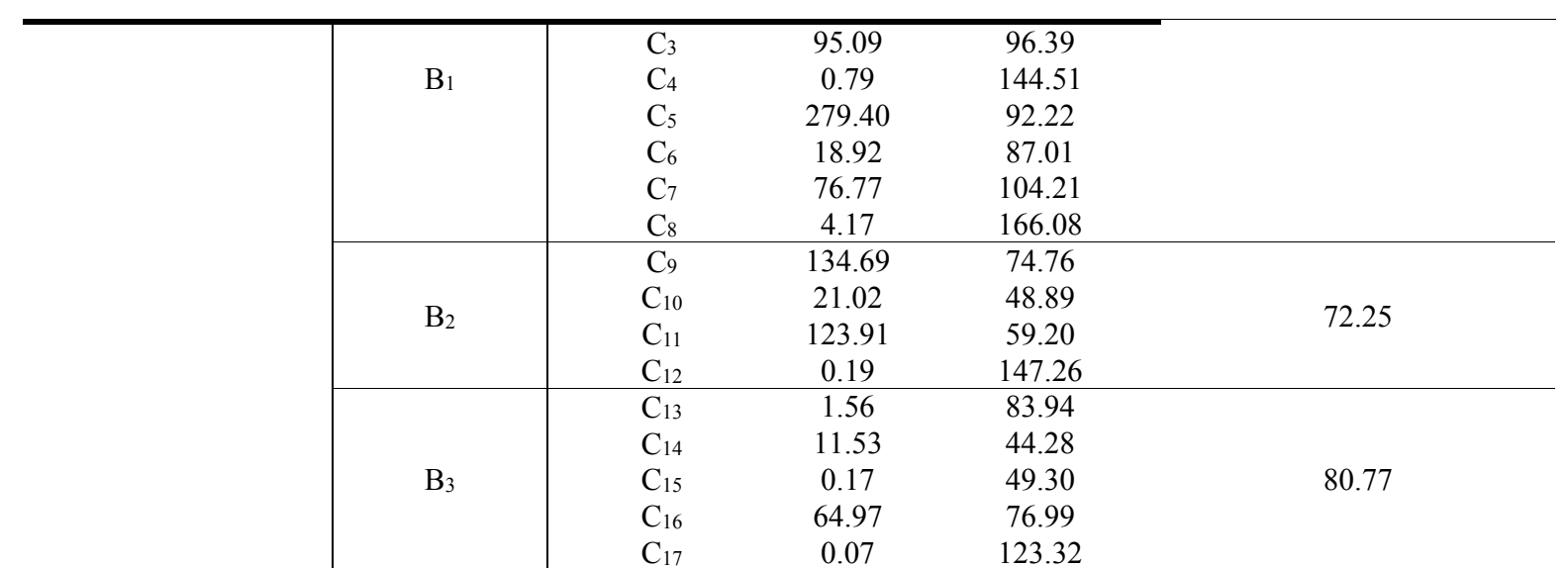

Compared with the target planning value in 2020, the comprehensive evaluation score of the development degree of land in this county was 108.24 , showing that the development and use degree of land was high. Wherein, the scores of various indicators from large to small were as follows: per capita area of construction land $>$ land construction use rate $>$ land reclamation rate $>$ forest coverage rate $>$ land use rate $>$ agricultural use rate of land $>$ multiple-crop indicator of cultivated land $>$ population density. The proportion of agricultural land was great, and agricultural land area was 296115.27 $\mathrm{hm} 2$, accounting for about $95 \%$ of the county's total land area. However, the land reclamation rate was only $1.37 \%$. This is because the county is located in the mountainous areas and affected by the geomorphic environment, and the fragmentation degree of land is great. In addition, in recent years, most rural young and middle-aged laborers have gone out to work, and the rural left-behind residents are mostly the elderly and the sick, resulting in tremendous changes in agricultural farming methods. In the cultivation process, the rural left-behind residents strived for simplicity and convenience and did not attach importance to maintaining the fertility of land, leading to the decline in the quality of cultivated land and the ineffective exploration of land potential. The proportion of construction land in the county was only $1 \%$, and the score of per capita area of construction land was 166.08, indicating that the industrial and mining land in urban areas was not enough; the sustained development of economy and society in the county has brought about a continuous increase in the demand for land, and the contradictions between the supply and demand of land will become more prominent and will restrict the overall development.

The evaluation score of the intensive management degree of land in the county was 72.25 , and the intensive use level of land was lower than the target planning value. Wherein, the scores of various indicators from large to small were as follows: road network density $>$ fertilizer application rate of per-unit cultivated land $>$ investment intensity of the fixed assets of per-unit construction land $>$ urbanization level. The score of urbanization was 48.89 , indicating that the urbanization level was not high. The score of road network density was 147.26, suggesting that the infrastructure land in the county was constantly being improved. From 2005 to 2016, the decline in per capita area of cultivated land, the prominent contradiction between people and land and the increase in various indicators of non-agricultural construction land in the county have led to the serious problems of the protection of cultivated land and will result in the increasingly incisive contradictions of the allocation of land resources in various industries in the future. The total amount of reserved resources for cultivated land in the county was $13240.24 \mathrm{hm} 2$, and the reserve resources for cultivated land suitable for development were relatively abundant. However, due to the insufficient development efforts, the situation of the sustainable use of land was not optimistic.

The evaluation score of the comprehensive benefits of land in the county was 80.77 , showing that the comprehensive benefits of land were preferable. Wherein, the scores of various indicators from large to small were as follows: per capita area of cultivated land $>$ output value of per-unit sown area $>$ land output rate $>$ total output value of per-unit agricultural land $>$ output value of per-unit cultivated land area. The scores of the output value of per-unit sown area, the output value of per-unit cultivated land area and the total output value of per-unit agricultural land were 83.94, 44.28 and 49.30, respectively. This was related to the surface structure characteristics of Baoxing County, and the relative fragmentation of cultivated land resulted in the low yields of food crops. The land output rate was relatively high, with the score of 76.99, and the economic crops in the mountainous and hilly areas were developing well, so the total land output rate was higher. Due to the low population density and the large proportion of agricultural land in the county, per capita area of cultivated land had a higher score of 123.32.

\section{Conclution and discussion}

The overall characteristics of land use in Baoxing County are the diversification of land use types and the imbalanced spatial distribution of various types of lands, and the evaluation score of the overall status was 83.5. At present, land use is at the relatively rational use stage, and the main problems are the lack of land investment, the low mechanization level of agricultural production and the urgent need to improve the use and development degree, the intensive level and the comprehensive benefits of land.

After the county experienced the $5 \cdot 12$ Wenchuan earthquake in 2008 and the $4 \cdot 20$ Lushan earthquake in 
2013, the number of hidden mountain disaster points has drastically increased, so the development of construction land is highly threatened by mountain disasters. Therefore, it is necessary to strengthen the existing financial investment in land, enhance the intensive degree of land and improve the mechanization level of agricultural production. At the same time, in the future process of use and development of land, there is a need to focus on the protection of ecological environment and the risks and management of mountain disasters, further carry out the suitability evaluation of land under the stress of mountain disasters and ensure the sustainable use of land resources.

\section{Acknowledgments}

We thank all funding support from the science and technology program in Guangdong province of China (Grant NO.2017A020220009), the 61st batch of Chinese postdoctoral program.(Grant NO.2017M612683), the south China normal university youth teacher scientific research cultivating fund program(Grant NO.2016JK102).

\section{References}

1. Chen G, Fang Y, Gao Y. China Mountain Development Report: New Developments and New Explorations of Mountainous Areas in China[M]. Commercial Press, 2010.

2. Wu C. Study of Land Use Evaluation in Urban Area and Analyzing its Potential: Taking Nanjing as an Example[D]. Naning Agricultural University, Naning, China, 2006.

3. Guo X, Qiu Y, Lian G, Liu K. The Progress and Prospect of Land Quality Indicators Based on"Press-State-Response" Framework[J].Progress in
Geography, 2003(05): 479-489.

4. Feslm FAO. An international framework for evaluating sustainable land management[R]. World Soil Resources Report 73.1993, 1993.

5. Wang X, Bao Y. Study on the Methods of Land Use Dynamic Change Research $[\mathrm{J}]$. Progress in Geography, 1999, 18(1): 81-87.

6. Malczewski J. Ordered weighted averaging with fuzzy quantifiers: GIS-based multicriteria evaluation for land-use suitability analysis[J]. International Journal of Applied Earth Observation and Geoinformation, 2006, 8(4): 270-277.

7. Chandio I A, Matori A N, Yusof $\mathrm{K}$, et al. GIS-basedland suitability analysis of sustainable hillside development[J]. Procedia Engineering, 2014, 77: 87-94.

8. Promper C, Puissant A, Malet J P, et al. Analysis of land cover changes in the past and the future as contribution to landslide risk scenarios[J]. Applied Geography, 2014, 53: 11-19.

9. Ozdemir A, Altural T. A comparative study of frequency ratio, weights of evidence and logistic regression methods for landslide susceptibility mapping: Sultan Mountains, SW Turkey[J]. Journal of Asian Earth Sciences, 2013, 64: 180-197.

10. Koomen E, Diogo V, Dekkers J, et al. A utility-based suitability framework for integrated local-scale land-use modelling $[\mathrm{J}]$. Computers, Environment and Urban Systems, 2015, 50: 1-14.

11. Wei H,Qin B,Peng J,Jin X. Evaluation on comprehensive exploitation suitability of low-slope hilly land based on GRNN model and neighborhood calculation:A case study of Wumeng Mountain continuous poverty-stricken region[J].Geographical Research, 2014, 33(5): 831-841. 